\title{
Law Blogging with Formative Peer-Assessment: Improving Students' Writing, Digital Skills and Assessment Literacy
}

Egle Dagilyte*

\section{A. Introduction}

Legal blogging - academic, professional, journalistic - carved out its space among blogs in the variety of industrial and social contexts. ${ }^{1}$ Blogging is also no longer news in legal higher education: ${ }^{2}$ many law firms and businesses use blogs as marketing tools, and some even ask students applying for employment to write a blog post, in order to assess their writing skills and communication abilities to non-specialist audiences. ${ }^{3}$ There have been a number of studies $^{4}$ that look at how blogging, as one of the Web2.0 tools, is used in higher education to

\footnotetext{
* Senior Lecturer in Law at Anglia Ruskin University and Fellow of the Centre of European Law at King's College London. Email: egle.dagilyte@anglia.ac.uk. I am thankful to Julian Krüper, Simon Lightfoot, Joaquin Noval, Steve Peers and Radosveta Vassileva for comments that helped improve this article. The usual disclaimer applies.
}

${ }^{1}$ A Bruns and J Jacobs (eds), Uses of Blogs (Peter Lang 2007).

${ }^{2} G$ Conole and P Alevizou, 'A Literature Review of the Use of Web 2.0 Tools in Higher Education' (HEA 2010) 29-30 https://www.heacademy.ac.uk/sites/default/files/conole_alevizou_2010.pdf accessed 30 August 2015.

${ }^{3}$ E Dagilyte, 'Law Academics Talk about Student Employability and Innovative Assessment at ABS Conference'

http://bucks.ac.uk/whoswho/school_of_applied_management_and_law/law/blog/ABS_Conference/ accessed 30 August 2015.

${ }^{4}$ Conole and Alevizou (n 2); T Franklin and M van Harmelen, 'Web 2.0 for Content for Learning and Teaching in Higher Education' (JISC 2007) https://staff.blog.ui.ac.id/harrybs/files/2008/10/web-2forcontent-for-learning-and-teaching-in-higher-education.pdf accessed 31 August 2015; JB Williams and J Jacobs, 'Exploring the Use of Blogs as Learning Spaces in the Higher Education Sector' (2004) 20 Australasian Journal of Educational Technology 232; JA Oravec, 'Bookmarking the World: Weblog Applications in Education' (2002) 45 Journal of Adolescent \& Adult Literacy 616; S Minocha and L Kerawalla, 'University Students' Self-Motivated Blogging and Development of Study Skills and Research Skills' in MJW Lee and C McLoughlin (eds), Web2.0-Based E-Learning (Information Science Reference 2011); HS Du and C Wagner, 'Learning With Weblogs: Enhancing Cognitive and Social Knowledge Construction' (2007) 5 IEEE Transactions on Professional Communication 1; $R$ Lamshed, $M$ Berry and L Armstrong, 'Blogs: Personal E-Learning Spaces' http://www.binaryblue.com.au/docs/blogs.pdf accessed 2 September 2015. 
support learning on a particular course. Although legal research ${ }^{5}$ and undergraduate student ${ }^{6}$ blogs are becoming commonplace, there are few documented attempts of teaching law blogging. Some examples include an Introduction to Legal Blogging course to graduate, postgraduate and doctorate law students in the form of weekly editorial meetings; ${ }^{7}$ a postgraduate law conference that encourages speakers to submit blog entries instead of papers prior to the conference; ${ }^{8}$ a reflective learning blog in a human rights module $;^{9}$ and using law firm blogs ${ }^{10}$ or academic blogs integrated with the author's textbook ${ }^{11}$ for teaching. Despite these developments, however, there seems a lack of literature on blogging in law classes, and in particular with relation to teaching European Union (EU) law. Moreover, we still know little about the precise ways blogging can improve university students' language proficiency or their digital skills.

To address this gap, this article will share experience on blog writing in law classroom, both from student perspective as well as from teaching perspective, raising questions whether module leaders and tutors of EU law should employ more blog writing exercises that are assessed either formatively or summatively, because law blogging engages students with the subject and helps develop multiple skills that graduate employers seek. ${ }^{12}$ Next to this main objective, this article highlights other issues that need to be investigated by further research on blogging as an innovative teaching and assessment method in law. These include whether

${ }^{5}$ See, e.g. 'KSLR EU Law Blog' https://blogs.kcl.ac.uk/kslreuropeanlawblog/ accessed 2 September 2015; 'EU Constitutional Law Blog' https://eulaworebro.wordpress.com/ accessed 2 September 2015.

6 Lawbore, 'Blogging Lawyers' http://lawbore.net/blog accessed 2 September 2015; We Are Warwick!, 'Student Blogs' http://studentblogs.warwick.ac.uk/law2/ accessed 2 September 2015.

${ }^{7}$ M Steinbeis, 'Verfassungsblog-Seminar Im WS 2015/16: Jetzt Bewerben!' (10 August 2015) http://verfassungsblog.de/verfassungsblog-seminar-im-ws-201415-jetzt-bewerben/\#.VFkMB_SG_5k accessed 5 January 2016.

8 'The Third Annual Edinburgh Postgraduate Law Conference' http://www.lawphdconference.ed.ac.uk accessed 22 December 2015.

${ }^{9}$ C Ashford, 'From Baghdad to Sunderland: Weblogs and Reflective Learning, or How I Learned to Stop Worrying and Love the Blog' (2007) 41 The Law Teacher 206.

10 'Alfil Abogados' http://alfilabogados.blogspot.com.es/ accessed 22 December 2015. Used by Joaquin Noval in Pablo de Olavide University, Spain.

11 'EU Law Analysis' http://eulawanalysis.blogspot.1t/ accessed 22 December 2015. Used by Steve Peers in University of Essex, UK.

${ }^{12}$ In 2013, the Legal Education and Training Review (LETR) emphasized the need to improve legal writing and drafting skills of law students; J Webb and others, Setting Standards: The Future of Legal Services Education and Training Regulation in England and Wales (Legal Education and Training Review 2013). 
blog writing helps with student retention; whether it develops student confidence in writing; whether it results in student confidence to tackle unfamiliar tasks in the future; whether and how it develops interest in EU law; and in what ways it enhances students' literateness and digital literacy.

Taking into account the mentioned objectives, this article, firstly, looks at the available literature on blogging in legal higher education. The author then proceeds to evaluate own experience of using blogging with formative peer-assessment at Buckinghamshire New University (Bucks) during two academic years (2013/14 and 2014/15) on LLB and LLM degrees in EU law modules.

\section{B. Student Blogging: the Bucks experience}

\section{Why Law Blogging?}

The original idea to ask students to write a blog post during the second EU Law seminar in 2013 was influenced by five reasons. Firstly, to encourage engagement with EU law as a subject, which many law students in Britain find hard to grasp, often due to its international roots, Euro-scepticism in British media and politics, as well as the fact that many EU cases originate from courts of other Member States and have names that are difficult for English native speakers to pronounce, not least because the need to learn and speak a foreign language does not feature heavily in British school curriculum. Given the above difficulties, there have been proposals to teach EU law not only as a stand-alone subject at undergraduate level, but as a discipline integrated in all other areas of national law, ${ }^{13}$ in order to show to students how important and relevant it could be in legal practice.

Secondly, even though it is widely assumed that the 'digital natives', are good with technology, research shows that many university entrants do not have essential text and data processing software or digital research skills, ${ }^{14}$ including - as the author's experience shows - how to insert comments and track changes in a Word document, or to use keyboard shortcuts. All of these skills are important

\footnotetext{
${ }^{13}$ D Edward, 'The "European” Content of British Law Degrees' (1995) 25 The Law Teacher 142.

${ }^{14}$ D Bates, 'Are “Digital Natives" Equipped to Conquer the Legal Landscape?' (2013) 13 Legal Information Management 172; JISC, 'Information Behaviour of the Researcher of the Future' (UCL 2008) CIBER Briefing Paper http://www.jisc.ac.uk/media/documents/programmes/reppres/gg_final_keynote_11012008.pdf accessed 30 August 2015. For the lack of digital research skills, 'digital natives' have even been branded as 'digital refugees': B Coombes, 'Generation Y: Are They Really Digital Natives or More like Digital Refugees?’ (2009) 7 Synergy 31.
} 
when writing a blog post. Moreover, blogging requires students to use technology in specific ways when researching a chosen topic (i.e. with the help of BOOLEAN search terms), as well as to find out how to use the set VLE platform ${ }^{15}$ onto which their blog entry is to be uploaded. Students' lack of digital skills stands in stark contrast with the vision of future lawyers as expert technologists, ${ }^{16}$ demanding that law students develop new technological skills if they are to be successful professionals. ${ }^{17}$ Today, this includes not only the advanced keyword e-searching, but also 'big data' analytics and the computer-guided predictive coding (ortechnology-assisted review), ${ }^{18}$ For these reasons, the BIALL's Legal Information Literacy Statement submitted to the Legal Education and Training Review recommended to prescribe 'modern lawyer' skills: demonstrating 'awareness of strengths and weaknesses in using social media ... such as legal blogs, ${ }^{19}$ and being able to present legal research findings to the intended audience via social media. ${ }^{20}$ Unfortunately, today's university entrants are nowhere near this IT proficiency level: they may be familiar with some searching tools, but this does not equate to information literacy required in this day and age. ${ }^{21}$ Therefore, it is essential that educators consider 'the technical and digital literacy skills of students (including prior blogging experience) and the training required to support the development of those skills, ${ }^{22}$ when blogging is introduced.

Thirdly, legal blogging helps students develop writing skills, as well as the ability to express their views by using hyperlinks (i.e. to 'reference' accurately). ${ }^{23}$ Students writing a blog post not only face the dilemmas as to what writing style to choose (informal/journalistic/academic), but also what kind of reliable sources to select, in order to support their statements and avoid bias in their writing. By becoming legal bloggers, law students can be likened to 'linkalists' - 'journalists whose authorial

${ }^{15}$ Blackboard was chosen for blogging, because it offered a smooth integration of the task and the supporting materials; as an internally hosted service it was a safe space for students to engage in a simulated online blogging environment.

${ }^{16} R$ Susskind, Tomorrow's Lawyers: An Introduction to Your Future (OUP 2013).

${ }^{17}$ MR Pistone, 'Law Schools and Technology: Where We Are and Where We Are Heading' (2015) 64 Journal of Legal Education 586, 589-591.

${ }^{18}$ Ibid 590.

19 Research Skill 5, BIALL, 'Legal Information Literacy Statement' (BIALL 2012) http://www.biall.org.uk/data/files/BIALL_Legal_Information_Literacy_Statement_July_2012.pdf accessed 2 September 2015.

${ }^{20}$ Research Skill 4, ibid.

${ }^{21}$ Bates (n 14) 176.

${ }^{22}$ Minocha and Kerawalla (n 4) 172.

${ }^{23}$ Oravec (n 4) 619. 
production consists largely of links to various Web resources along with reflections and critical commentary. ${ }^{24}$

In the fourth place, the exercise sought to encourage students to read each other's work that was uploaded on VLE blogging platform, in order to allow for it to be assessed according to the assessment criteria that were applied for summative assessments on the LLB/LLM programmes. Therefore, by so creating a peer-to-peer feedback and marking environment, the blog-marking exercise was intended to create a two-way student-lecturer understanding on what assessment involved, reducing anxiety and stress before submission deadlines and before mark release deadlines, ${ }^{25}$ in line with the literature on assessment for learning ('feed-forward'), rather than assessment of learning. ${ }^{26}$ The exercise highlighted that it was not easy to mark others' work, not least because different markers often ended up with different marks, even though they applied the same marking criteria.

Finally, the author hoped that blogging in EU law could encourage student active and deep learning, ${ }^{27}$ in turn increasing student retention, reducing drop-outs and resulting in higher academic achievement as indicated by research in $\mathrm{STEM}^{28}$ and in legal studies. ${ }^{29}$ By forcing the boundaries of students' comfort zones to engage actively ${ }^{30}$ with the subject matter in a new, creative way, it was expected that blogging could transform and empower learners to investigate an EU law topic of their choice, by creating a text that can be shared publicly. ${ }^{31}$

\section{Student Demographics and Activity Design}

In terms of demographic coverage, students on EU law modules on Bucks LLB programme were mostly locally-based, with higher percentage of non-EU students on LLM programmes. Gender was not a major differentiator; in all classes there were students from non-white

${ }^{24}$ ibid 620; Williams and Jacobs (n 4) 3.

${ }^{25}$ See HEA, 'A Marked Improvement: Transforming Assessment in Higher Education' (2012) https://www.heacademy.ac.uk/sites/default/files/a_marked_improvement.pdf accessed 31 August 2015.

${ }^{26}$ RJ Stiggins, Student-Involved Assessment FOR Learning (4th edn, Prentice Hall 2004).

${ }^{27}$ EA Kirley, 'Are We Ethically Bound to Use Student Engagement Technologies for Teaching Law?' (2015) 49 The Law Teacher 219, 223.

${ }^{28} S$ Freeman and others, 'Active Learning Increases Student Performance in Science, Engineering, and Mathematics' (2014) 111 Proceedings of the National Academy of Sciences 8410.

${ }^{29}$ PW Hatamyar and TP Sullivan, 'The Impact of Active Learning on Law School Performance' (2011) 3 Journal of Multidisciplinary Research 67.

${ }^{30}$ RM Felder and R Brent, 'Active Learning: An Introduction' (2009) 2 ASQ Higher Education Brief 2.

${ }^{31}$ Lamshed, Berry and Armstrong (n 4). 
ethnic groups. With regard to classroom size, the usual cohort in attendance was 5-30 students in weekly EU law seminars.

After Bucks LLB degree revalidation in 2013, the year-long EU Law module continued to be taught for year-two students on the 'old' LLB, while a semester-long module EU Constitutional and Procedural Law began to be taught to first-year students in spring semester on the 'new' LLB programme. This allowed running blogging seminars with LLB year-one and year-two students and with LLM students in 2013-2015.

For each year cohort, during the first introductory EU law seminar, the tutor would explain how the module would run and in what ways EU law affected lives of ordinary citizens, including young people. Following the introduction, students were instructed to upload a blog post on 'How EU law affects my life' via Blackboard Wikis tool before the second seminar of the module. They were also asked to print a hard copy of the text and to bring it to class where it was to be marked, without being told who would mark their work. As research ${ }^{32}$ and experience shows, it is important to incorporate some assessment element into class activities for the likelihood of performance of the set task. ${ }^{33}$

During the second seminar, all blogs were anonymously peer-assessed: multiple students graded multiple blog posts, resulting in more than one mark for each post. All marks for all blog posts were then noted by the tutor on the whiteboard, usually resulting in wide ranges of marks for the same submission. This 'visual map' was then succeeded by a class discussion on how students found marking, which blog posts they enjoyed reading most and why; how bias (i.e. marking a friend's blog post) influenced their decision on mark allocation; or what could be the reasons for huge differences in marks. Finally, after the student discussion had taken place, tutor feedback for each blog was distributed to each student personally, providing further comments and an indicative grade (the 'feed-forward'), along with encouragement for improvement and publication on the Department's blog for the best blog posts.

\footnotetext{
${ }^{32}$ M Cole, 'Using Wiki Technology to Support Student Engagement: Lessons from the Trenches' (2009) 52 Computers \& Education 141.

${ }^{33}$ A Kirkwood and L Price, 'Learners and Learning in the Twenty- ${ }^{\circ} \odot$-first Century: What Do We Know about Students' Attitudes towards and Experiences of Information and Communication Technologies That Will Help Us Design Courses?' (2005) 30 Studies in Higher Education 257, 272.
} 


\section{Findings: Potential Problems with Blogging}

Next to the positive change that blogging exercises brought to class, there were three key challenges that arose during the two years of teaching blogging at Bucks.

\section{Lack of Student Understanding what Legal Blogging Is}

To begin with, some students were not sure how informal their post should be, and whether, or how, it is different from a summatively assessed essay. This is a natural reaction: because of its characteristics of a conversation, storytelling and debate, blogging is 'different from writing an essay, literature review, or other academic paper. ${ }^{34}$ This was the first ever attempt to blogging for most Bucks students, or even a first attempt to writing a journalistic piece, whether in online environment or, for example, for a student law journal. Faced with an unfamiliar task, they became anxious, which is a natural reaction, as research on cognitive psychology demonstrates. ${ }^{35}$ Nevertheless, many responded positively: they asked the tutor questions either in class or via email, or discussed issues with peers.

To empower and enable students further, the author found it helpful to look at some leading blogs on EU law, and for this purpose compiled a list of most influential EU law blogs to follow. ${ }^{36}$ In this way, the existing recommended blogs assisted students when making choices as to what writing style to use, what kind of topics they could write about, how to attribute image copyright, or how to hyperlink and reference the statements and ideas online. Next to this, during the first EU law seminar, the author played online videos that explored different ways in which EU law affected daily lives of European citizens. This seems to have inspired some students and allowed them to replay the videos while searching for a topic.

\footnotetext{
${ }^{34}$ Minocha and Kerawalla (n 4) 172.

${ }^{35}$ S Ohlsson, Deep Learning: How the Mind Overrides Experience (CUP 2011) 235.

${ }^{36}$ For an updated list, see E Dagilyte, 'Top 10 European Union Law Blogs to Follow' http://bucks.ac.uk/whoswho/school_of_applied_management_and_law/law/blog/eu-blogs-to-follow/ accessed 30 August 2015.
} 


\section{Insufficient Student Digital Skills}

It is common that learners faced with a new e-learning task may find it daunting, even though it could have been explained/shown in class in advance. This applies also to the use of technology for writing a blog post. At Bucks, students had to upload their posts onto the VLE (Blackboard) that had a Wikis plug-in. Most students had their own laptop/computer/tablet, or had access to the University's computers, so this did not raise widening participation concerns in terms of economic factors. ${ }^{37}$ To assist the students with technological challenges, the author produced a guide (see Annex I) with screenshot images explaining what users were going to see on the screen. This seems to have worked in practice, as there were only few student queries on how to use the system. Given the small and closely-knit class cohort of maximum 40 students in the same year of study, informal student feedback indicated that they helped each other in order to tackle new technologies, in this way minimising the need to contact their tutor.

There were, of course, instances where students did not upload their blog posts onto Blackboard Wikis, and instead brought them to class only as a print out, or did not bring/prepare anything at all. However, it is unclear whether the lack of preparation was the result of the insufficient student IT or writing skills, or whether it occurred because students did not have time to prepare as instructed. Looking at the two years' experience, the latter cause of behaviour could be more likely, but empirical research would be required to determine precise reasons, possibly taking into account individual students' overall performance on the whole degree.

All in all, the technological side of the task, it seems, was unfamiliar to students only to a certain extent: Blackboard Wikis allow for a post to be written using MS Word and then copy-pasting the text into the online text editor on Blackboard, while retaining the MS Word text formatting. This meant that students could write their post in a familiar manner, instead of using Blackboard Wikis online editor directly, in this way guaranteeing satisfactory experience with blogging, without technology obstructing of the writing task. ${ }^{38}$

There were, nevertheless, two main areas where more substantial difficulties arose with regard to technology. The first one was how to reference ideas with the use of hyperlinks:

\footnotetext{
${ }^{37}$ Franklin and van Harmelen (n 4) 23.

${ }^{38}$ Minocha and Kerawalla (n 4) 172.
} 
often students inserted full hyperlinks inside the text, rather than hyperlinking the text. The second difficulty was acknowledging copyright of the image used for the text. Blog writing instructions purposely included the use of copyrighted images, in order to highlight to the students that non-attribution of image copyright involves ethical concerns, is against the law and could also constitute academic misconduct (plagiarism). ${ }^{39}$ As Lippincott observes, issues such as intellectual property, privacy and the freedom of expression 'are fundamental to operating as an informed citizen in today's information society and directly affect the work of individuals who create, as well as use, networked information. ${ }^{40}$ In the light of these observations, it would be useful to amend the author's guide about blogging via Blackboard Wikis, by including image-based instructions on how to insert hyperlinks and how other law blogs attribute image copyright.

\section{Problems with Student Literacy}

According to Mosesson, law is not just a body of knowledge, but a disciplined activity which requires a wide range of different skills that are necessary for $u \operatorname{sing}$ law, ${ }^{41}$ including literacy, ${ }^{42}$ reading and synthesizing long and complex texts, or writing in a clear and coherent manner. ${ }^{43}$ Learning these skills and engaging in this activity of 'lawyering' is essential if one is to become a lawyer.

However, legal educators are aware that students' reading and writing skills at the beginning of a law degree are often nowhere near the required professional standard, ${ }^{44}$ because 'an increasing number of students are coming into universities with fewer skills of literateness

\footnotetext{
${ }^{39}$ Franklin and van Harmelen (n 4) 23.

40 J Lippincott, 'Net Generation Students and Libraries' in DG Oblinger and JL Oblinger (eds), Educating the Net Generation (EDUCAUSE 2005) $13.6 \mathrm{http} / / / \mathrm{www} . e d u c a u s e . e d u /$ educatingthenetgen accessed 20 August 2015.
}

${ }^{41}$ Time management and personal organisation, information management, critical thinking, awareness of copyright and avoiding plagiarism, networking, communication, and a variety of research skills; See Minocha and Kerawalla (n 4) 169.

${ }^{42}$ L Mosesson, 'Legal Education in a Semi-Literate Culture' (2011) 13 Mountbatten Journal of Legal Studies 63, 66.

${ }^{43}$ See the learning outcomes as stated in the QAA Subject Benchmark Statement for Law (2015; especially paras 3.3, 3.5, 3.7), the Law Society and Bar Council Joint Statement on the academic stage of training (2002; especially Sch 1 Part b), BIALL Legal Information Literacy Statement (2012), and the LETR Report (2013).

${ }^{44}$ Hatamyar and Sullivan (n 29). 
and less interest in literateness. ${ }^{45}$ Coupled with the finding that law students do not read in full what is recommended by their tutors when preparing for weekly seminars, including reading cases $;{ }^{46}$ this presents the blogging task as a difficult and often unwelcome exercise at the beginning of an academic year for first-year and often second-year law students. Of course, without good reading and writing skills it is difficult to produce a blog post of publishable quality from a first attempt. Therefore, at Bucks, prior to publication, the best students were asked to improve their text, taking into account the tutor's feedback. Two such blog posts were published on the Law Department's blog. ${ }^{47}$ There were other students, who, from this experience, later became blog writers, ${ }^{48}$ including at a local law firm ${ }^{49}$ or editing of the University's student newspaper.

\section{Evaluation and Conclusions}

As identified in this article, blogging in EU law or any other legal discipline could serve as a useful exercise that improves student writing abilities, and develops their IT skills; it can be organised as a peer-assessment exercise, in order to bridge the gap between students and

${ }^{45}$ Mosesson (n 42) 73. He defines literateness as 'the ability to read and write intelligently and carefully, and the appreciation of, and the desire to develop, the use of language in a way that is more than merely demoticly functional'; ibid 63 .

${ }^{46}$ For student challenges with reading legal texts and suggestions how to overcome them, along with effective reading strategies used by the successful law students, see LM Christensen, 'Legal Reading And Success In Law School: An Empirical Study' (2007) 30 Seattle University Law Review 603. On whether it is important for students to read cases in full, see L Yeatman, 'Do LLB Students Read Cases?', ALT Annual Conference 'All Consuming Legal Education' (2013) http://www.lawteacher.ac.uk/docs/yeatman-presentation.pdf accessed 31 August 2015. Bates also notes that due to students opting for 'information shortcuts' via Google and Wikipedia, many do not understand the wider context in which a case may have been decided (e.g. whether it was overruled, or whether there are later judgments building on it): Bates (n 14) 174.

${ }^{47}$ A Vranch, 'There Will Be Fireworks on Bonfire Night: A Quick Look at the EU's Pyrotechnic Directive' http://bucks.ac.uk/whoswho/school_of_applied_management_and_law/law/blog/BonfireNight/ accessed 31 August 2015; A Mahmood, 'Religious Freedom and the Freedom of Expression Uneasy Bedfellows?' https://bucks.ac.uk/whoswho/school_of_management_and_professional_studies/law/blog/religious_fre edom/ accessed 22 December 2015.

48 Patel, 'Studying Law on Erasmus ${ }^{+}$in Heidelberg, Germany' https://bucks.ac.uk/whoswho/school_of_management_and_professional_studies/law/blog/LawErasmu s/ accessed 22 December 2015.

49 'Lawdit Music Blog' http://www.lawditmusic.co.uk/music-law-blog/?author=11 accessed 22 December 2015. 
tutors about the purpose and nature of assessment in legal studies. With the greater awareness of other established EU law blogs, blogging can engage students in interesting debates in EU law seminars, with the chosen topics at Bucks ranging from human rights protection in Europe, to the 'funny shape' of bananas, firework safety, animal testing in cosmetics industry, or migration.

In this article, the author discussed potential difficulties that law blogging may pose to students, such as lack of prior understanding what law blogging involves, underdeveloped student writing skills and a likely lack of the required IT literacy. As suggested, these can be overcome by producing effective student guides about how the task is to be organised, together with a list of reputable existing law blogs and freely available video materials that generate ideas and creativity for writing. Clearly, the use of Web2.0 tools in higher education can produce no results if there is no 'instructional scaffolding': ${ }^{50}$ student guides how to use the technology (i.e. blogging platform), examples of 'good' legal blogging, and advice how to acknowledge copyright and insert hyperlinks in a blog post.

It is important to point out that the aim of the blogging task in EU law seminars at Bucks was not about an extremely well-written blog post, but about a process of writing itself and about improving graduate skills such an exercise is likely to produce, in combination of students becoming aware how assessment works on law degree modules. Of course, in an ideal world, every student-written post would be publishable on a reputable legal blog. In reality, however, this first blogging exercise is only student introduction into the 'world of blogging', which could be especially interesting for the students who begin to find writing a pleasure, aim for higher employability profile, or strive for both. Therefore, law blogging could be a useful tool to encourage learners to write better and more often, expressing their ideas to a wider audience, at the same time increasing their self-autonomy and developing critical thinking. ${ }^{51}$ Law blogging could also be seen as an exercise that helps develop law students' skills and qualities of mind, encapsulating a vast mix of 'the intellectual abilities and attributes of graduates in law, including but not limited to legal knowledge and understanding. ${ }^{, 52}$ Arguably, writing a blog post on how EU law affects their lives, students are encouraged not only to act as independent researchers, but also as independent learners, building on the

\footnotetext{
${ }^{50}$ Reasons for non-engagement with the set task can include pressures from other courses, concerns about how to use the technology, self-confidence, or a total lack of interest; see Cole (n 32).

${ }^{51}$ Oravec (n 4) 618.

52 QAA, 'Subject Benchmark Statement for Law' (2015) 5 http://www.qaa.ac.uk/en/Publications/Documents/SBS-Law-15.pdf accessed 30 August 2015.
} 
information that they had been given in the first introductory EU law seminar. In this way, from knowledge acquisition they are encouraged to progress to participation and knowledge creation, which is 'the ultimate goal of learning in the knowledge age. ${ }^{53}$

Alongside these findings and the author's reflections on law blogging at Bucks, it is clear that future research on law blogging is required, in order to gather empirical qualitative data on student and tutor experiences about writing blogs in law classroom, or using them via different pedagogies and alternative assessment methods. As it is still an innovative type of exercise, there is a growing need to investigate whether it is effective and for what purposes; whether it may be summatively assessed; what other challenges it may present to students, tutors and learning support staff. While doing so, it is important to keep in mind that fluent writing, technology and digital literacy are not just 'library' or 'IT' problems. ${ }^{54}$ they need to be taught in all years of law degrees, integrated in the law curriculum and also require tutors who possess such skills and are passionate about passing them to future law students. Thus law blogging poses not only learning challenges for students, but also professional development challenges for educators and institutions. ${ }^{55}$ There is, it seems, a long way to go for all parties concerned, if blogging is to be used effectively in law classroom to replicate possible demands of future graduate careers.

\section{Bibliography}

Ashford C, 'From Baghdad to Sunderland: Weblogs and Reflective Learning, or How I Learned to Stop Worrying and Love the Blog' (2007) 41 The Law Teacher 206.

Bates D, 'Are "Digital Natives" Equipped to Conquer the Legal Landscape?' (2013) 13 Legal Information Management 172.

BIALL, 'Legal Information Literacy Statement' (BIALL 2012) http://www.biall.org.uk/data/files/BIALL_Legal_Information_Literacy_Statement_July_2012.pdf accessed 2 September 2015.

Bruns A and Jacobs J (eds), Uses of Blogs (Peter Lang 2007).

Christensen L, 'Legal Reading And Success In Law School: An Empirical Study' (2007) 30 Seattle University Law Review 603.

${ }^{53}$ C McLoughlin and MJW Lee, 'Social Software and Participatory Learning: Pedagogical Choices with Technology Affordances in the Web 2.0 Era', ICT: Providing choices for learners and learning. $\begin{array}{lllll}\text { Proceedings } & \text { ASCILITE } & \text { Singapore } & 2007 & \text { (2007) }\end{array}$ http://bilby.unilinc.edu.au/webclient/StreamGate?folder_id=0\&dvs=1441028297744 39\&usePid1=tru e\&usePid2=true accessed 30 August 2015.

${ }^{54}$ Lippincott (n 40) 13.7.

${ }^{55}$ Minocha and Kerawalla (n 4) 173. 
Cole M, 'Using Wiki Technology to Support Student Engagement: Lessons from the Trenches' (2009) 52 Computers \& Education 141.

Conole $G$ and Alevizou P, 'A Literature Review of the Use of Web2.0 Tools in Higher Education' (HEA 2010) https://www.heacademy.ac.uk/sites/default/files/conole_alevizou_2010.pdf accessed 30 August 2015.

Coombes B, 'Generation Y: Are They Really Digital Natives or More like Digital Refugees?' (2009) 7 Synergy 31 .

Dagilyte E, 'Law Academics Talk about Student Employability and Innovative Assessment at ABS Conference',

http://bucks.ac.uk/whoswho/school_of_applied_management_and_law/law/blog/ABS_Conference/ accessed 30 August 2015.

Dagilyte E, 'Top 10 European Union Law Blogs to Follow'

http://bucks.ac.uk/whoswho/school_of_applied_management_and_law/law/blog/eu-blogs-to-follow/ accessed 30 August 2015.

Du H and Wagner C, 'Learning With Weblogs: Enhancing Cognitive and Social Knowledge Construction' (2007) 5 IEEE Transactions on Professional Communication 1.

Edward D, 'The "European" Content of British Law Degrees' (1995) 25 The Law Teacher 142.

Felder R and Brent $R$, ‘Active Learning: An Introduction' (2009) 2 ASQ Higher Education Brief.

Franklin T and van Harmelen M, 'Web 2.0 for Content for Learning and Teaching in Higher Education' (JISC 2007) https://staff.blog.ui.ac.id/harrybs/files/2008/10/web-2-for-content-forlearning-and-teaching-in-higher-education.pdf accessed 31 August 2015.

Freeman S and others, 'Active Learning Increases Student Performance in Science, Engineering, and Mathematics' (2014) 111 Proceedings of the National Academy of Sciences 8410.

Hatamyar P and Sullivan T, 'The Impact of Active Learning on Law School Performance' (2011) 3 Journal of Multidisciplinary Research 67.

HEA, 'A Marked Improvement: Transforming Assessment in Higher Education' (2012)

https://www.heacademy.ac.uk/sites/default/files/a_marked_improvement.pdf accessed 31 August 2015.

JISC, 'Information Behaviour of the Researcher of the Future' (UCL 2008) CIBER Briefing Paper http://www.jisc.ac.uk/media/documents/programmes/reppres/gg_final_keynote_11012008.pdf accessed 30 August 2015.

Kirkwood A and Price L, 'Learners and Learning in the Twenty-first Century: What Do We Know about Students' Attitudes towards and Experiences of Information and Communication Technologies That Will Help Us Design Courses?' (2005) 30 Studies in Higher Education 257.

Kirley E, 'Are We Ethically Bound to Use Student Engagement Technologies for Teaching Law?' (2015) 49 The Law Teacher 219.

Lamshed R, Berry M and Armstrong L, 'Blogs: Personal E-Learning Spaces' http://www.binaryblue.com.au/docs/blogs.pdf accessed 2 September 2015.

Lippincott J, 'Net Generation Students and Libraries' in DG Oblinger and JL Oblinger (eds), Educating the Net Generation (EDUCAUSE 2005) http://www.educause.edu/educatingthenetgen accessed 20 August 2015.

Mahmood A, 'Religious Freedom and the Freedom of Expression - Uneasy Bedfellows?' https://bucks.ac.uk/whoswho/school_of_management_and_professional_studies/law/blog/religious_fre edom/ accessed 22 December 2015.

McLoughlin C and Lee M, 'Social Software and Participatory Learning: Pedagogical Choices with Technology Affordances in the Web 2.0 Era', ICT: Providing choices for learners and learning. Proceedings ASCILITE Singapore 2007 (2007) 
http://bilby.unilinc.edu.au/webclient/StreamGate?folder_id=0\&dvs=1441028297744 39\&usePid1=tru e\&usePid2=true accessed 30 August 2015.

Minocha S and Kerawalla L, 'University Students' Self-Motivated Blogging and Development of Study Skills and Research Skills' in MJW Lee and C McLoughlin (eds), Web2.0-Based E-Learning (Information Science Reference 2011).

Mosesson L, 'Legal Education in a Semi-Literate Culture' (2011) 13 Mountbatten Journal of Legal Studies 63.

Ohlsson S, Deep Learning: How the Mind Overrides Experience (CUP 2011).

Oravec J, 'Bookmarking the World: Weblog Applications in Education' (2002) 45 Journal of Adolescent \& Adult Literacy 616.

Patel $S$, 'Studying Law on Erasmus+ in Heidelberg, Germany'

https://bucks.ac.uk/whoswho/school_of_management_and_professional_studies/law/blog/LawErasmu s/ accessed 22 December 2015.

Pistone M, 'Law Schools and Technology: Where We Are and Where We Are Heading' (2015) 64 Journal of Legal Education 586.

Stiggins $R$, Student-Involved Assessment FOR Learning (4th edn, Prentice Hall 2004).

Susskind R, Tomorrow's Lawyers: An Introduction to Your Future (OUP 2013).

Vranch A, 'There Will Be Fireworks on Bonfire Night: A Quick Look at the EU's Pyrotechnic Directive' http://bucks.ac.uk/whoswho/school_of_applied_management_and_law/law/blog/BonfireNight/ accessed 31 August 2015.

Webb J and others, Setting Standards: The Future of Legal Services Education and Training Regulation in England and Wales (Legal Education and Training Review 2013).

Williams $J$ and Jacobs $J$, 'Exploring the Use of Blogs as Learning Spaces in the Higher Education Sector' (2004) 20 Australasian Journal of Educational Technology 232.

Yeatman L, 'Do LLB Students Read Cases?', ALT Annual Conference 'All Consuming Legal Education' (2013) http://www.lawteacher.ac.uk/docs/yeatman-presentation.pdf accessed 31 August 2015. 